\title{
Review of Studies on Digital Transaction Platforms in Marketing Journals
}

\author{
Mikko Hänninen ${ }^{1}$ \\ This is an accepted manuscript of an article published by Taylor \& Francis in The International \\ Review of Retail, Distribution and Consumer Research on 14.8.2019, available at \\ https://doi.org/10.1080/09593969.2019.1651380
}

\begin{abstract}
Digital transaction platforms now intermediate a large number of transactions between end-customers and independent sellers and service providers in many parts of the economy. In retail, for example, Amazon.com now intermediates transactions between end-customers and hundreds of thousands of independent sellers worldwide, while Etsy.com connects artists, crafters, and collectors with buyers of a large range of niche and rare products. The growing popularity of digital transaction platforms, therefore, has significant implications for retail, marketing and distribution scholars as the existing interaction patterns in the value-chain are increasingly replaced by new digital intermediaries. The purpose of this review is, therefore, to examine, through an extensive and rigorous review of research on digital transaction platforms in marketing journals, what we know and what opportunities lie ahead to expand the theoretical and empirical understanding of digital transaction platforms. The review shows that despite increasing multi-disciplinary and managerial interest towards digital transaction platforms, they remain largely unexplored in marketing journals, and the existing research and theorizing attempts remain fragmented. Therefore, there are many opportunities for marketing, retail and distribution scholars to, for example, collaborate with industry and practitioners in order to gain new perspectives and access to novel data sources, and for example, meet the emerging funding requirements of many universities and governmental funding agencies for multi-disciplinary research on digital markets and digital business models.
\end{abstract}

Keywords: Digital transaction platforms, multi-sided markets, review, marketing,

\section{INTRODUCTION}

The recent decade has seen increasing academic and managerial interest towards digital transaction platforms as the 'platform revolution' (Parker, Van Alstyne and Choudary 2016) has led to the rise of platform-based business models in a number of industries. This has invited large multi-disciplinary interest into digital transaction platforms and multi-sided markets. In retail, digital transaction platforms have reconfigured the business logic from the sale of products and services directly to endcustomers, to the intermediation of exchanges between suppliers and end-customers through an online digital interface (e.g., Hänninen, Mitronen and Kwan, 2019). For example, Alibaba.com, a digital transaction platform, that connects millions of independent Chinese sellers and Western brands

\footnotetext{
${ }^{1}$ Aalto University School of Business, Department of Marketing, Espoo, Finland Email: mikko.o.hanninen@aalto.fi
} 
with end-customers worldwide, is on course to bypass Walmart as the largest retailer in the world by 2020 , with a gross merchandise value (GMV, value of all transaction intermediated) of over $\$ 800$ billion (e.g. Alibaba Group, 2019). On the other hand, Amazon.com, which follows a hybrid model in which half of its sales come from independent sellers through the Amazon Marketplace, now accounts for around 50\% of all online shopping in the US (e.g. eMarketer, 2018).

As digitalization has created new mediums for the exchange of products, services and information (e.g., Brynjolfsson and McAfee 2014), scholars have aimed to understand the emerging business models in addition to theorizing about their implications on marketplace behavior (e.g., Perren and Kozinets 2018). Especially digital transaction platforms have received widespread interest, as they have, for example, contributed to the rise of the gig, collaborative and sharing economy (e.g., Burtch, Carnahan and Greenwood 2018; Belk 2014) and access-based services (e.g., Schaefers et al. 2016, 4). As such, through the popularity of digital transaction platforms, the buyers and sellers of different types of products and services can now interact more effectively (e.g., Caldieraro et al. 2018). For example, customers can now bypass the retailer and the incumbent interaction patterns in the valuechain, by participating in digital transaction platforms and forming virtual value-chains (e.g. Kahn, Inman and Verhoef, 2018). As a result, today online communities, such as social media platforms like Facebook, enable users to form social ties with other users and share information, ideas and interests (e.g., Park et al. 2018), while online marketplaces, such as Amazon.com, connect buyers and sellers together across borders (e.g., Fang et al. 2015).

While for both customers and suppliers' digital transaction platforms provide new transaction and interaction opportunities, they also have fundamental implications for retailers and marketers as incumbent channels in the retail and marketing mix are being replaced by digital alternatives (Kannan, 2017). However, despite the significant implications of digital transaction platforms for marketing, retail and distribution, digital transaction platforms have only received limited attention in marketing journals, and there is yet potential to develop this still 'nascent' (Sriram et al. 2014, 143) and 'limited' (Perren and Kozinets 2018,21) field of literature, for example, in order to come up with a viable research agenda. As one exception, Sriram et al. (2015) provide a review of the multidisciplinary research on digital transaction platforms and encourage marketing scholars to make more substantive and methodological advances in this field, by (i) finding empirical support for the existing theoretical advances, (ii) taking advantage of the new possible data streams digital transaction platforms provide, and (iii) developing new methods and techniques to study digital transaction 
platforms. This call for research, however, does not consider how marketing scholars can grasp the more large-scale implications of digital transaction platforms and build theoretical insights.

Adopting the definition of McIntyre and Srinivasan (2017, 141), in this review digital transaction platforms are defined as platforms that intermediate 'transactions among firms and/or individuals that may not be able to transact otherwise'. Accordingly, the purpose of this review is to understand how the disruption digital transaction platforms bring to marketing, retail and distribution is reflected in research published in marketing journals. Research on digital transaction platforms is therefore reviewed in order to take a snapshot of what we know and what opportunities lie ahead to expand theoretical and empirical understanding of digital transaction platforms.

The rest of the paper is organized as follows. First, the conceptual background and definitions for digital transaction platforms are presented. Second, the methodology of the review, including a description and justification of article extractions are presented. Finally, the results, limitations, and conclusions of the study are presented together with a discussion of future research possibilities.

\section{CONCEPTUAL BACKGROUND}

The power of digital transaction platforms compared to the incumbent interaction patterns in the value-chain comes from their ability to harness a large group of multi-sided users and the value of the interactions that the platform intermediates between these distinct user groups (Gawer and Cusumano 2014). Uber and Airbnb have for example radically transformed the transportation and accommodation industries respectively, by lowering the entry barriers for becoming a service provider (e.g., Burtch, Carnahan and Greenwood 2018; Kuhn and Maleki 2017), as a digital transaction platform now intermediates transactions and ensures quality between end-users and thirdparty service providers. As a result of the disruption brought by digital transaction platforms, scholars have become interested in understanding how firms organize around them (e.g., Jacobides, Cennamo and Gawer 2018).

Digital transaction platforms are transforming the economy, by 'resetting entry barriers' and 'changing the logic of value creation and value capture' (Kenney and Zysman 2016, 66). For example, by not being related to or under the control of any one retailer (Hall and Towers 2017), the network of participants on digital transaction platforms is more important than the features or attributes of any single product or service whose exchange it intermediates (Perks et al. 2017). As 
transactions between retailers, suppliers and end-customers increasingly take place via digital transaction platforms, Ramaswamy and Ozcan $(2018$, 19) for example argue that through the 'technological revolution', the primary offering of many firms are now digitized artifacts, where value is created through a combination of 'artifacts, persons, processes and interfaces' rather than any physical products or services per se.

In retail, as digital transaction platforms like Alibaba or Amazon.com own little, if any, fixed, physical assets, their earnings are usually based on commissions from the exchanges that they intermediate between the platform's users (e.g., Hänninen, Mitronen and Kwan, 2019). In addition, digital transaction platforms use the data about these exchanges to, for example, personalize the platforms offering (Khan 2017). Network effects (Parker and Van Alstyne 2005) mean that a large number of users on one side of a digital transaction platform, for example suppliers, will usually lead to a large number of users on the other side of the platform, meaning that digital transaction platforms often enter a self-reinforcing cycle where each new user on the platform makes the platform even more dominant, as new user enables the platform to accumulate more data about their behavior (Tiwana 2014).

As the platform-based business model has transformed how suppliers and end-customers interact, also marketing scholars have acknowledged the significance of digital transaction platforms and their relevance to marketing theory (Mathmann et al. 2017). Thus, several studies in marketing journals have confirmed the potential of digital transaction platforms and multi-sided markets to reorganize industrial structures and competitive dynamics, for example, in the retail (e.g., Hänninen, Mitronen and Kwan, 2019), media (e.g., Kanuri, Mantrala and Thorson 2017), accommodation (e.g., Zervas, Proserpio and Byers 2017) and music industries (e.g., Datta, Knox and Bronnenberg 2018). According to Bharadwaj et al. $(2013,472)$, this is due to digital transaction platforms and advances in information technology shaping business into something that is 'modular, distributed, crossfunctional and global.' However, despite the broad interest into the disruptive elements of digital transaction platforms in marketing journals, most research is still focused on defining the basic properties of digital transaction platforms and multi-sided markets, for example in terms of their economic and competitive implications (Sriram et al. 2015). This plenitude of interest towards digital transaction platforms has prompted diverse streams of research into them. McIntyre and Srinivasan (2017) for example, distinguish between the different streams of platform research and describe them as (i) industrial economics, (ii) technology management and (iii) strategy, focusing on questions such as the existence of direct and indirect network effects, how platforms attract third-party sponsors, and 
how platforms may receive and maintain competitive advantage, respectively. From these, marketing scholars have focused primarily on the latter, seeking to understand the business models of 'trnansaction' platforms which facilitate transactions between buyers and sellers (Sriram et al. 2015), and also the nature of these digital transaction platforms in terms of their network structure (Chu and Manchanda 2016), and the strategic and tactical choices related to their use (Jiang, Jerath and Srinivasan 2011).

Digital transaction platforms are identified to have significant implications on marketing theory, for example, in areas such as customer behavior (e.g., Park et al. 2018; Chakravarty, Kumar and Grewal 2014) and firm performance (e.g., Mathmann et al. 2017; Chu and Manchanda 2016). In marketing literature, digital transaction platforms are found to now intermediate the transactions of different types of products and services between customers (C2C), businesses (B2B) and a combination of them (B2C). However, regardless of the type of transactions intermediated by the platform, digital transaction platforms, and multi-sided markets share similar characteristics. For example, Perren and Kozinets $(2018,248)$ argue that although lateral exchange markets (LEM) include activities popularly defined as the 'sharing economy', they also fit the more general platform definition by facilitating 'technologically intermediated exchanges between the members of a network of buyers and sellers'. Perren and Kozinets (2018) classify ' $L E M$ ' markets into four categories: (i) forums, (ii) enablers, (iii) matchmakers and (iv) hubs, which include platforms that enable the buying, selling, renting, trading, bartering and swapping of products and services. In another recent paper, Crittenden, Crittenden and Crittenden (2017) apply the Evans and Gawer (2016) categorization of (i) transaction platforms, (ii) innovation platforms, (iii) integrated platforms, and (iv) investment platforms, to argue that the new exchange and transaction opportunities intermediated by digital transaction platforms and multi-sided markets have significant marketing and retail implications due to the heightened customer expectations they entail.

\section{METHODOLOGY}

\section{Article extraction}

Step 1: Inclusion

The initial search of articles was based on the keyword 'platform' in Elsevier's SCOPUS database, the largest global database of peer-reviewed academic literature. The database was scanned for the 
'platform' keyword in the abstract, title and keyword list of articles included in the database and published in peer-reviewed English language journals belonging to the business, management, and accounting subject area. The first step in article extraction generated 7,784 results for the 'platform' keyword. Inclusion criteria were specified to systematize the search and review, as listed below:

Inclusion criteria (Step 1):

IC1. Include studies found using the keyword "platform"

IC2. Include studies published before December 2018

IC3. Include journal articles published in English language

IC4. Include journal articles

IC5. Include articles in the business, management and accounting subject area

Step 2: Exclusion

First, the results were narrowed down to only include journals within the marketing discipline. The 2018 ABS Journal Guide published by the Chartered Association of Business Schools was consulted in order to only included studies published in marketing journals. The ABS Journal Guide is a guide to the range and quality of journals in which business and management academics publish their research and is used by many universities worldwide as a benchmark to assess the achievements of academic faculty, for example, when making tenure decisions. Articles published in one of the 70 journals ranked and listed as part of the marketing discipline in the 2018 ABS Journal Guide were included for further analysis. The second step in article extraction generated 525 articles published in marketing journals ranked and listed in the 2018 ABS Journal Guide.

Second, full texts of the published articles were then examined by the author to exclude those that are not associated with digital transaction platforms as per their research focus or the McIntyre and Srinivasan (2017) definition of digital transaction platforms. In addition, studies published in the past 20 years (between 1999 and 2018) were examined in order to filter out ambiguous and irrelevant uses of the 'platform' construct as per the scope of this review. For example, due to the lack of the 'transaction' aspect of the McIntyre and Srinivasan (2017) definition, studies focusing on social media platforms (e.g., Barcelos et al. 
2018) and online virtual communities (e.g., Baka 2007) were excluded from further analysis. Exclusion criteria (step 2) were specified in order to systematize the search and review, as listed below:

\section{Exclusion criteria (Step 2):}

EC1. Exclude studies not published in marketing journals ranked in the 2018 ABS journal guide

EC2. Exclude studies on the basis of relevance

EC3. Exclude the duplicate studies with matching titles and/or Digital Object Identifier (DOI)

EC4. Exclude studies published before 1999. In the current study, 1999 is used as the cut-off because using a longer period might not yield any more relevant studies)

\section{Step 3: Final set}

This final step in article extraction generated 51 articles published between 2011 and 2018, and in 21 different marketing journals ranked in the 2018 ABS Journal Guide (see Appendix for a full list of articles included in the final set including descriptive information about each study). To ensure that only the most relevant studies are selected, the articles found using the search syntax and laid down review protocol were analyzed in depth through content analysis of abstracts and full papers. Thereafter, the short-listed articles were classified, organized and analyzed The analysis of the 479 articles was repeated by the author using the same review protocol, and no further articles were found and included in the final set. The review process was iterative, and articles were critically evaluated against the inclusion and exclusion criteria throughout the search and analysis process.

\section{Data analysis}

The selected articles from 21 marketing journals were then analyzed through a comprehensive classification framework focusing on broad thematic, theoretical and methodological dimensions. As per the notions of content analysis, this framework enabled to 'examine communication systematically' (Abbott and McKinney 2013, 316), and provide an in-depth understanding of the focus of the research (Shapiro and Markoff 1997). The thematic dimension was denoted by the type of digital transaction platform studied and theoretical focus. The theoretical dimension was denoted by the definition of a digital transaction platform, and the theoretical contribution. In addition, the 
methodological dimension was denoted by research design, which enabled to understand the research designs and empirical data used to study digital transaction platforms. The framework was enacted through a comprehensive coding scheme, including coding variables that were coded through reading the full text of the 51 articles.

Place Figure 1 about here

Figure 1 provides an overview of the literature review. The review demonstrates that the keyword 'platform' has become a buzzword in marketing journals that is used by numerous scholars. However, many articles that include the keyword do not, in fact, focus on digital transaction platforms as per the scope of this review. Thus, several unrelated uses of the term 'platform' were found. For example, platforms are often used to refer to, for example in advertising, media and product innovation contexts to, more or less, 'unique scientific principles' (Sood and Tellis 2011, 340), 'on which firms manufacture products to service customers in a particular market', without the transactional element of the McIntyre and Srinivasan (2017) definition. The excessive use of the 'platform' keyword to refer to other platforms than digital transaction platforms and multi-sided markets, largely explains the vast number of articles excluded during the second step of the analysis. The following section discusses the results of the analysis.

\section{FINDINGS}

This section provides an analysis of the 51 journal articles identified through the article extraction, with regard to broad thematic, theoretical and methodological dimensions.

\section{Thematic dimensions}

Types of digital transaction platforms studied

Place Table 1 about here 
By definition, digital transaction platforms intermediate transactions between at least two distinct groups of users. As a result of the increasing multi-disciplinary interest towards digital transaction platforms (e.g., McIntyre and Srinivasan 2017), digital transaction platforms were found to have been studied from different perspectives also in marketing journals. The studied platforms mediate exchanges between customers (C2C), businesses (B2B) and a combination of them (B2C). Table 1 describes these research streams in more detail. About three fifths, 55\% $(n=28)$ of the articles focus on B2C platforms, $28 \%(n=31)$ on $\mathrm{C} 2 \mathrm{C}$ platforms and $14 \%(\mathrm{n}=7)$ on B2B platforms, with authors employing explicitly stated theories, conceptual frameworks or theoretical models to study one of these types of digital transaction platforms.

B2C digital transaction platforms are defined to intermediate transactions between customers and businesses for a wide range of products and services. Research on B2C platforms has been motivated by digital transaction platforms such as Amazon.com, iTunes and Google Play becoming dominant in their respective industries (Mathmann et al. 2017). For example, Ramaswamy and Ozcan (2018) argue that as a result of digitalization and the technological revolution, most offerings to customers can now be described as 'interactive platforms'. Examples of research on B2C platforms include Lacan and Desmet (2017) who study a crowdfunding platform, Landsman and Stremech (2011) who study digital transaction platforms in the video game industry and Jiang, Jerath, and Srinivasan (2011) who study Amazon.com and the asymmetric information between Amazon and the third-party suppliers. Some B2C platforms include elements of both B2B and C2C. For example, online group buying, and daily-deal platforms meet the definition of a B2C platform (Chiu et al. 2018; Ieva, De Canio, and Ziliani, 2018; Song et al. 2016), by mediating transactions between both customers and the suppliers that offer deals via the platform. On the other hand, crowdfunding and microfinance platforms are somewhat of an exception as they have generated research from both a $\mathrm{B} 2 \mathrm{C}$ and $\mathrm{C} 2 \mathrm{C}$ perspective, with Caldieraro et al. (2018), Bollinger and Yao (2018) and Maier (2016) studying such platforms from a B2C perspective, while Lacan and Desmet (2017) and Komarova and Gonzalez (2015) study such platforms from a C2C perspective.

C2C digital transaction platforms are defined to intermediate transactions between customers, by providing a medium for end-customer to transact electronically with one another (Saarijärvi, Joensuu, Rintamäki and Yrjölä 2018). The increasing number of C2C platforms has led to the adoption of the popularly used terms 'sharing economy' (e.g., Belk 2014), peer-to-peer markets (Proserpio, Xu and Zervas, 2018) and 'access-based services' (e.g., Schaefers et al. 2016), which refer to digital transaction platforms through which customers can exchange different types of products and services 
with other customers either for free or for a payment of some sort. Examples of research on $\mathrm{C} 2 \mathrm{C}$ platforms include Caldieraro et al. (2018) who study a peer-to-peer lending market, the Lending Club, Zervas, Proserpio and Byers (2017) who study the impact of Airbnb on the hotel and accommodation industry in Texas and Yrjölä et al. (2017) who study customer motivations for using C2C platforms. Some research extends the definition of $\mathrm{C} 2 \mathrm{C}$ platforms to also include social communities (e.g., Park et al. 2018; Qu et al. 2013; Seraj et al. 2012), as online social communities emphasize the social ties between individuals using a digital transaction platform. On the other hand, Perren and Kozinets $(2018,20)$ adopt their own definition for C2C platforms, describing them as 'social platforms' that intermediate transactions between customers, with 'social platforms' forming markets where the exchanges take place between 'equivalently positioned economic actors'. While social media platforms fall out of the scope of this review due to the lack of the 'transact' part of the McIntyre and Srinivasan (2017) definition, some researchers have on the other hand studied the social and communal elements of $\mathrm{C} 2 \mathrm{C}$ platforms, including the relationship between online reviews and seller quality (Zhang, Luo and Li 2012), the role of trust in the use of C2C platforms (Mittendorf 2018), the use of Facebook as a C2C platform (Saarijärvi, Joensuu, Rintamäki and Yrjölä, 2018), and the drivers for engaging in $\mathrm{C} 2 \mathrm{C}$ transactions via social media platforms such as Instagram (Yahia, Al-Neama and Kerbache 2018).

B2B digital transactions are defined as business-to-business electronic markets that intermediate transactions between businesses. Examples include Li, Li and Wang (2018) who focus on the incentive strategies of sellers using a large B2B electronic platform marketplace, Perks et al. (2017) who focus on value platforms built around and evolved through the joint actions of the network members using the platform and Muzellec, Ronteau and Lambkin (2015) who study the business model evolution of digital transaction platforms from a B2C to a B2B focus.. In addition, digital transaction platforms such as platforms in the media industry (Kanuri, Mantrala and Thorson 2017; Sridhar et al. 2011) fall into this category, as these digital transaction platforms also include two distinct user groups: readers and advertisers, and the studies focus on understanding how to maximize their revenue from both sides of users.

\section{Theoretical focus}

The theoretical focus captures the primary theories, conceptual frameworks or theoretical models that have been applied in each article to motivate and guide the research. The 51 articles include several different theoretical focus areas, including advertising, assortments, budgeting, business models, 
customer orientation, decision-making, matchmaking, multihoming, practice theory, pricing, return behavior, risk transfer, signaling, trust, and value creation. From these different theoretical focus areas, the majority of articles, $88 \%(\mathrm{n}=45)$, focus on micro-level theorizing, such as the implications of digital transaction platforms on specific marketing theories, and $12 \%(n=6)$ on the more macrolevel implications of digital transaction platforms.

Micro-level studies on digital transaction platforms focus on understanding questions such as the customer profiles of users of C2C platforms (Saarijärvi, Joensuu, Rintamäki and Yrjölä, 2018), business strategies of digital transaction platforms (Kabakova, Plaksenkov and Korovkin 2016), attitudes towards digital transaction platforms (Lacan and Desmet 2017), and topics such as information asymmetry (Caldieraro et al. 2018), signaling (Jiang, Jerath and Srinivasan 2011), marketing budgeting (Sridhar et al. 2011), and customer orientation (Chakravarty, Kumar and Grewal 2014). Studies such as Kaushik et al. (2018), Thakur (2018) and Zhang, Luo and Li (2012) focus on the social aspects of digital transaction platforms, online reviews, and study their effect on sales performance, customer engagement and their reliability as an indicator of seller quality, respectively. All of these articles have provided incremental advances to increasing understanding of the impact of digital transaction platforms on different aspects of marketing theory. From these multihoming, signaling, information transmission and pricing have also received multi-disciplinary interest in other disciplines (e.g., Sriram et al. 2015), for example, from an economics and competition perspective. On the other hand, studies on the business model lifecycle of digital transaction platforms, marketing budgeting, and customer orientation represent more traditional marketing related research areas, which the authors now study in a digital transaction platform context. Interestingly, topics such as industry transformation have only received limited research, even though, besides the studies on Airbnb and the hotel and accommodation sector by Proserpio and Zervas (2018) and Zervas, Proserpio and Byers (2017), platforms have become dominant in numerous other industrial settings as well (e.g. Mathman et al. 2017).

Macro-level studies seek to theorize about the implications of digital transaction platforms on, for example, incumbent marketing and sales channels. Examples include Ramaswamy and Ozcan (2018) who theorize about the larger implications that the technological revolution has on the offering of firms and Perren and Kozinets (2018) who propose a framework for understanding different types of ' $L E M$ '. Besides these examples, other studies have taken a macro-level perspective through a review of prior literature, with Sriram et al. (2015) seeking to understand the overall state of digital transaction platform research, and others, like Alt and Klein (2011) and Hall and Towers (2017), 
acknowledging that digital transaction platforms play a major role as one factor that is causing major changes for retailers. Furthermore, for example, Barnes and Pressey $(2012,167)$ argue that the 'virtual worlds' intermediated by digital transaction platforms are becoming increasingly important channels through which firms can communicate with both their current and potential customers.

\section{Summary}

The review shows that marketing scholars have focused primarily on studying B2C platforms rather than digital transaction platforms that mediate either $\mathrm{C} 2 \mathrm{C}$ or $\mathrm{B} 2 \mathrm{~B}$ relationships. However, despite a smaller absolute number of studies, research on $\mathrm{C} 2 \mathrm{C}$ platforms focuses on more macro-level thematic issues, while research on B2C and B2B platforms have received advances on more micro-level thematic issues. For example, as an example of a macro-level thematic study, Perren and Kozinets $(2018,21)$ argue that $\mathrm{C} 2 \mathrm{C}$ platforms often form ' $L E M$ ' in which technological intermediated exchanges take place between customers, or in their words 'actors occupying equivalent network positions'. This increased macro-level thematic interest amongst marketing scholars on C2C platforms is motivated by these platforms emerging as alternatives to incumbent marketing and retail channels, with individual customers now becoming the suppliers of several types of products and services, for example by participating in sharing economy platforms like Airbnb and Upwork.

\section{Theoretical dimensions}

\section{Definition of platforms}

The review identified several definitions for digital transaction platforms, a sample of which are shown in table 2. These definitions draw, for example, on Rochet and Tirole (2006), to describe digital transaction platforms as multi-sided or two-sided markets, that enable the interaction of two, or more, sides of distinct groups of users. Unanimous to most of these definitions is that digital transaction platforms are 'complex information technology systems' that are open to both customers and partners (Kabakova, Plaksenkov and Korovkin 2016, 1106), with the platform acting as a 'central intermediary' (Lacan and Desmet 2017, 472) for intermediating transactions between platform users (Perren and Kozinets 2018). Out of the 51 articles, 45\% ( $=23)$ include a specific definition for digital transaction platforms. 
Place Table 2 about here

The most common definition of digital transaction platforms defines them as multi-sided or twosided, regardless of the type of transaction (B2C, C2C, or B2B) intermediated by the platform. The common denominator of these studies is that digital transaction platforms are comprised of two distinct and interdependent groups of users, i.e. buyers and sellers (e.g., Muzellec, Ronteau and Lambkin 2015), and the platform acts as an intermediary between these distinct groups of users (Albuquerque 2012). Examples of these definitions include Sridhar et al. (2011, 929-930) who argue that an inherent characteristic of digital transaction platforms is that they intermediate interactions between 'two or more different groups of customers', more specifically, 'two or more distinct groups of customers interested in different offerings of the platform', Crittenden, Crittenden and Crittenden (2017) who argue that digital transaction platforms are a distribution channel of their own and Chakravarty, Kumar and Grewal $(2014,1)$ who argue that the interaction between two or more sides of users as a condition for value generation makes digital transaction platforms 'distinct from traditional B2B relationships'. Chakravarty, Kumar and Grewal (2014) use the example of Ford to support their argument, as Ford's suppliers have traditionally not been viewed as its customers or required to interact with its end-customers, while for digital transaction platforms this duality would be natural as each distinct group of users is a customer and the platform owner seeks to maximize the value of each side of platform users. As a result, digital transaction platforms need to simultaneously attract both sides of users to the platform (Fang et al. 2015), and the decisions taken by one set of agents will likely have an effect on the other 'via direct and/or indirect externalities' (Sriram et al. 2015, 142). On the other hand, for example, Proserpio, Xu and Zervas (2018) argue that critical to the definition of digital transaction platforms is that they entail the close interaction of buyers and sellers.

Besides two-sided markets, a wide range of other definitions were also found in the articles, for example, defining digital transaction platforms as a business model $(n=2)$, social community $(n=2)$, and interactive platform $(\mathrm{n}=1)$. Examples of these definitions include Jiang, Jerath, and Srinivasan $(2011,761)$ who define digital transaction platforms as a business model, with the business model of platforms like Amazon.com, found to extend outside the core platform to a 'plethora of products and services' that are being turned into platforms, Park et al. $(2018$, 93) who argue that online communities can be defined as digital transaction platforms as they are dominant platforms 'for individuals to form social ties with other users and share information, ideas, and interests', and 
Ramaswamy and Ozcan $(2018,19)$ who argue that central to digitalized networked arrangements, such as digital transaction platforms, is the 'interactional creation of value'. In addition, alternative definitions were also offered to describe multi-sided or two-sided markets. Mathmann et al. (2017, 212) for example, define digital transaction platforms as digital intermediaries that 'enable economic transactions between two sets of agents, such as retailers and customers'.

\section{Theoretical contribution}

The theoretical contribution considers the extent to which research seeks to expand existing knowledge in a given field (e.g., Whetten 1989). For empirical articles, the theoretical contribution can be generally categorized as theory testing or theory building, in other words, whether a study seeks to primarily test an existing theory or build new theory respectively. On the other hand, the contribution of review articles and other conceptual advances can be labeled as exploratory, as they aim to create an understanding for topics that have not yet received much theoretical interest, and thus seek to explore rather than theorize (e.g., Stebbins 2001). In marketing journals, theory testing accounted for about two-thirds $(n=36)$ of the research on digital transaction platforms, while exploratory and theory building articles each about one-sixth ( $\mathrm{n}=7$ and $\mathrm{n}=8$ respectively).

First, theory testing articles seek to contribute to research through the use of empirical observations to test theoretical propositions. For example, articles following a theory testing approach build their hypotheses on existing theory, and then test these hypotheses with one or more empirical observations (e.g., Colquitt and Zapata-Phelan 2007). In marketing journals, theory testing articles on digital transaction platforms primarily derive their hypotheses from marketing theory and test them on empirical data from a B2C, C2C or B2B platform. Examples include Caldieraro et al. (2018) who study signaling in the context of a crowdfunding platform, Guyader (2018) who applies practice theory to study different usage patterns of ridesharing services, Park et al. (2018) who study the role of networks in customer spending, and Landsman and Stremerch (2011) who study multi-homing in the video-game industry. While theory testing studies primarily ground their hypothesis on marketing theory, the theoretical aim can also be to illustrate the impact of a contextual phenomenon as is the case with Zervas, Proserpio and Byers (2017), as well as Proserpio, Xu, and Zervas (2018), and their research on Airbnb. While theory testing articles are anchored on existing theories, they may also in part extend theory by identifying new constructs and applications for theories (e.g. Kapoor and Vij, 2018). 
Second, exploratory articles seek to explore a particular phenomenon, but, in general, do not aim to theorize or suggest further theoretical avenues for inquiry (e.g., Stebbins 2001). Most of the exploratory articles on digital transaction platforms in marketing journals focus on describing the implications of digital transaction platforms on the marketing discipline or one of its sub-disciplines, but rather than seeking to test or build new theory, they only acknowledge these implications and the emerging research opportunities. Examples include Sriram et al. (2015) who provide an overview of digital transaction platform related research opportunities, Cho, Fu and $\mathrm{Wu}$ (2017) who acknowledge the interest towards digital transaction platforms and network-based business models in marketing journals, and Crittenden, Crittenden and Crittenden (2017) who describe digital transaction platform led industry disruption. In addition, the papers using mathematical modeling, Hossain and Morgan (2013), Jiang, Jerath and Kannan (2011), and Wu, Zhang, and Padmanabhan (2018), fall into the exploratory category, as although providing mathematical evidence about a particular theoretical problem such as firm-strategies, matchmaking, and market tipping, they generally fall short in theorizing and suggesting new theoretical avenues.

Thirdly, theory building articles seek to contribute to research by introducing original theoretical concepts, constructs or relationships (e.g., Colquitt and Zapata-Phelan 2007). Most of the theory building articles develop novel theoretical frameworks to understand the implications of digital transaction platforms. Examples include Ramaswamy and Ozcan $(2018,19)$ who propose a novel framework of digitalized interactive platforms, that considers the changing nature of value creation from artifacts, persons, processes and interfaces as 'means' for creating value, rather than as 'having value', Perren and Kozinets (2018) who create a framework of 'LEM', categorizing these digital transaction platforms as forums, enablers, matchmakers and hubs, Kanuri, Mantrala and Thorson (2017) who draft a theory-driven model related to profit maximization in the media industry through the design of subscription 'menus' for both readers and advertisers, and Chakravarty, Kumar and Grewal (2014) by adapting the construct of customer understanding to a triadic platform setting. In addition, theory building articles often seek to theorize about the implications of digital transaction platforms on competition, customer behavior and strategy. For example, Datta, Knox and Bronnenberg (2018) conduct a study on the effects of online music streaming platforms on music consumption and discovery, Saarijärvi, Joensuu, Rintamäki and Yrjölä (2018) identify distinct customer profiles of users on C2C platforms, and Ritala, Golnam and Wegmann (2014) study the coopetition-based business model of Amazon.com.

\section{Summary}


Most studies on digital transaction platforms in marketing journals were found to share a definition for digital transaction platforms. Following the definition by Rochet and Tirole (2006), digital transaction platforms are described in most studies as two-sided markets that enable the interactions and exchanges between two or more sides of economic actors. In terms of the theoretical approach, especially concerning is the large amount of theory testing compared to theory building articles. When taking a closer look at the theory building articles, most of these studies focus on building theory regarding specific types of digital transaction platforms, rather than seeking to build theory to capture the phenomena at large. One example of such studies is Ramaswamy and Ozcan (2018) who create their own definition for digital transaction platforms and adopt their own terminology to describe the phenomena. On the other hand, there is also room for theory testing articles to anchor their theoretical contribution on more classical marketing theories. Theoretical domains such as customer orientation, customer value, and customer experience design have only received limited theoretical interest in a digital transaction platform context, although customer centricity and customer-centric strategies are arguably crucial aspects to consider with regard to digital transaction platforms and multi-sided markets. Finally, only a handful of exploratory studies were found. There is thus more room for exploratory studies that seek to describe the larger implications of digital transaction platforms on exchange relationships and incumbent marketing channels, in addition to more conceptual advances that seek to theorize rather than only describe the transformation taking place as a result of the platform revolution.

\section{Methodological dimensions}

\section{Research Design}

A research design describes the empirical approach used by scholars. For example, de Vaus (2001, 16) defines research design as the 'structure of an enquiry'. The articles were first analyzed based on their method of enquiry, in particular, whether they relied on qualitative or quantitative data, and then based on their specific research design. Of the empirical articles $(n=46), 74 \%(n=34)$ follow quantitative methods while $20 \%(\mathrm{n}=9)$ rely on qualitative methods. The remaining $6 \%(\mathrm{n}=3)$ use mathematical modeling to draft their contribution.

Five distinct quantitative research designs were identified: longitudinal $(n=19)$, surveys $(n=11)$, case study (1), and experiments $(\mathrm{n}=3)$. As digital transaction platforms enable the generation and analysis 
of large, novel datasets (Sriram et al. 2015), the majority of the quantitative articles rely on longitudinal and cross-sectional data, for example, gathered from a specific digital transaction platform or industry, often from a particular time period. Examples of longitudinal (or, in some cases, cross-sectional) studies include Caldieraro et al. (2015) who analyze 26,314 loan applications gathered from Lending Club archives, Park et al. (2018) who analyze log data of 4,645 individual gamers on a multiplayer online role-playing game, $\mathrm{Li}$, Li and Wang (2018) who study 605 merchants over a two week period registered in a large B2B platform in China, and Landsman and Stremerch (2011) who analyze sales data of 12 home video game consoles from between 1995 and 2008. In terms of measuring the more large-scale implications of digital transaction platforms on music consumption, Datta, Knox and Bronnenberg (2018) study longitudinal panel data of individual users listening histories from multiple digital music streaming platforms to understand how the use of streaming platforms, such as Spotify, alter music consumption and discovery habits. As a result of the reliance on large datasets, surveys, for example, are only used in 11 articles. On the other hand, as examples of studies that use longitudinal or cross-sectional data to focus on single firm or industry, Chakravarty, Kumar and Grewal (2014) conduct interviews with decision-makers of platform firms, which are then analyzed using statistical methods and Lee et al. (2018) use time-series data with 18 million buyers and sellers to conduct a quasi-experiment.

Qualitative approaches were applied through three distinct research designs: case studies $(n=4)$, interviews $(n=2)$ and ethnography $(n=3)$. From the case studies, Kabakova, Plaksenkov, and Korovkin (2016), Muzellec, Ronteau and Lambkin (2015) and Perks et al. (2018) use a multiple case study design in their research, while Ritala, Golnam, and Wegmann (2014) rely on a single case study. Field-level interviews formed the primary empirical data of two articles. Gao et al. (2016) conduct interviews with New Zealand SME's using a shopping platform to enter the Chinese market, in addition to conducting interviews with the platform's managers, while Thaichon and Quach (2016) conduct interviews with both buyers and sellers of counterfeit products on digital transaction platforms. In addition, varieties of the ethnographic method were used by Guyader, (2018), Perren and Kozinets (2018) and Seraj (2012). Guyader (2018) conducted participant observation and interviews with users of the Blablacar ridesharing platform, Perren and Kozinets (2018) adopted a 'market-oriented ethnography' approach by participating in 193 different 'LEM' over 6 years, while Seraj et al. (2012) adopted netnography to understand the main characteristics of online communities.

In addition to research using quantitative or qualitative methods, mathematical modeling was also used to study digital transaction platforms in 3 articles. Jiang, Jerath and Srinivasan (2011) provide a 
model of the strategies of platform owners to respond to the actions of sellers, $\mathrm{Wu}$, Zhang and Padmanabhan (2018) model the pricing of matchmaking services and their network effects, while Hossain and Morgan (2013) model the more general performance and competitive implications of digital transaction platforms.

\section{Summary}

The review shows that marketing scholars increasingly rely on large, longitudinal and cross-sectional data-sets, as their primary empirical data. Despite the new opportunities provided by these large-data sets, the review was skewed towards longitudinal and cross-sectional data sources, compared to, more contemporary, marketing research designs, such as surveys, case studies, and interviews. The review also identified a skewed relationship between the use of quantitative versus qualitative methods. The use of qualitative methods (e.g., ethnographic, historical, interpretive) combined with the large, realtime, cross-sectional quantitative data sources available from digital transaction platforms, would enable scholars to triangulate and cross-validate findings related to digital transaction platforms, and understand, in more detail, the implications of different types of digital transaction platforms on, for example, incumbent marketing and sales channels. Although qualitative designs are rarely used to study digital transaction platforms, the few studies that do use such designs, such as, Muzellec, Ronteau, and Lambkin (2015), promise interesting results that help understand the impacts and the evolution of digital transaction platforms and platform-based business models. This type of understanding is important in order to generate more theoretical insight.

\section{DISCUSSION}

Digital transaction platforms have gained increasing attention from marketing scholars over the past few years, and the number of articles published on the topic has grown considerably. This study reviewed and synthesized the current state of research on digital transaction platforms through a systematic review of 51 articles published in 21 marketing journals according to broad thematic, theoretical and methodological dimensions.

At the end of each of sub-section of the paper, the analysis was summarized and more specific issues in need of further research were presented. Many of these suggestions involved the need to broaden the empirical knowledge base and make more ambitious theoretical contributions to extend theoretical understanding of digital transaction platforms. This is important as the studies on digital 
transaction platforms in marketing journals were found to share many different definitions for digital transaction platforms, use primarily quantitative methodologies and focus on a combination of B2C, $\mathrm{C} 2 \mathrm{C}$ or $\mathrm{B} 2 \mathrm{~B}$ platforms with manifold divergent, and often incompatible, concepts and terminologies. Moreover, the majority of the reviewed studies only sought to test rather than build new theory. It would be useful for marketing scholars to thus build more reliable empirical generalizations of digital transaction platform in order to generate more theoretical insights about the phenomena at large. This would help integrate the currently fragmented research on digital transaction platforms in marketing journals.

I conclude with some suggestions to broaden the conceptual scope of research on digital transaction platforms in the marketing discipline. First, in this review, digital transaction platforms were defined as platforms that intermediate transactions amongst firms and or individuals that may not be able to transact otherwise (McIntyre and Srinivasan, 2017). However, despite some commonalities in the definition of a digital transaction platform across the reviewed studies, the current research has adopted distinct concepts, definitions and terminologies depending on whether the platform intermediates transactions between end-customers (C2C), firms (B2B) or a combination of them (B2C). While digital transaction platforms may start out as exclusively C2C, B2B or B2C oriented, they often intermediate a combination of these exchanges (e.g. Alibaba Taobao Marketplace, C2C; Alibaba.com, B2B; and Alibaba Tmall, B2C) and therefore such strict separations or definitions should not be used in a discipline as broad as marketing. Moving away from defining these platforms only through the type of transactions mediated to exploring the more in-depth mechanisms of platform-based businesses, would help generate more rigorous empirical insight regarding digital transaction platforms.

Second, most of the research has so far focused on the performance implications of digital transaction platforms for the focal firm or industry. Little, if any, attention has been devoted to understanding how and why digital transaction platforms are used, and what benefits, if any, they deliver to the distinct actors using the platform, such as the retailer, supplier, and end-customer. Hänninen, Mitronen, and Kwan (2019), for example, argue that through the emergence of the platform revolution the customer experience in the retail and consumer services sectors has become centered on convenience, customization, engagement, price, selection and speed. On the other hand, Kahn et al. (2018) argue that for both retailers and supplier's, macro trends such as the emergence of large digital transaction platforms, omnichannel shopping, technological change, the era of big data, increased number of digitally native end-customers, and vertical integration are creating significant 
disruption and altering the competitive landscape, particularly due to the popularity of digital transaction platforms. From these trends vertical integration is especially critical, as through digital transaction platforms end-customers and suppliers can now bypass the retailer and the incumbent interaction patterns in the value-chain, for example, by delivering products directly from the factory to the end-customer. However, much of this discussion on the macro, rather than the micro level implications of the platform revolution, are largely missing from the reviewed studies on digital transaction platforms in marketing journals. Furthermore, as the interactions between retailers, suppliers, and end-customers on digital transaction platforms take place through increasingly complex and entangled platform ecosystems, in which the platform extends to a host of supplementary services and networks, there is a need for scholars to also understand the distinct characteristics of such ecosystems, including their evolution and growth. More research on the processes and mechanisms through which different types of digital transaction platforms impact marketing and retail activities for retailers, suppliers, and end-customers is therefore called for.

Finally, the empirical world around us keeps on generating new, large longitudinal and crosssectional data sets. As digital transaction platforms continue to be largely unexplored in marketing journals, by tapping into these novel and rich data sources there is potential to produce, 'more managerially relevant research' which does not only focus on 'merely advancing sophisticated research methods' (Kumar 2017, 1). For example, through collaboration with industry and practitioners marketing scholars could gain access to unique, large data-sets, and also better grasp the wider societal implications of digital transaction platforms and multi-sided markets. Through this collaboration, scholars can seek to add value to the existing knowledge base, rather than focusing on thematic issues that are irrelevant or self-explanatory, and thus do not extend theory nor practice. In addition, multi-disciplinary research projects, increasingly promoted by universities and governmental funding agencies worldwide, may also offer marketing scholars the ability to undertake more rigorous theory building regarding digital transaction platforms. By being a part of multidisciplinary research projects, it is possible for marketing scholars to stay on top of digital developments and potentially enable marketing scholars to become frontrunners in understanding the ongoing digital transformation and the implications of further technological developments on the discipline.

With this literature review, the existing marketing research on digital transaction platforms is summarized. This review will hopefully be helpful for fellow marketing scholars to identify gaps in the literature and better understand the nature of digital transaction platforms. A couple of things, 
however, need to be considered regarding the generalizability of this review. First, as the findings emerged from a review of studies published in a subset of marketing journals, the findings cannot be fully generalized to the wider marketing literature, including, for example, conference publications and non-published, work-in-progress manuscripts. In addition, while the purpose of this review to capture the state of research on digital transaction platforms specifically in marketing journals, marketing scholars may also publish their research in, for example, journals belonging to the broad business and hospitality disciplines. Second, although the present study provides invaluable insights about the state of digital transaction platform research in marketing journals, there are still a number of avenues for further empirical and conceptual studies on digital transaction platforms, that will hopefully build upon the analysis presented in this review. Future studies may find it useful to focus on a larger number of studies and articles, also in the sister disciplines to marketing, such as strategic management, and use, for example, quantitative methods such as meta-analysis, to further analyze and quantify some of the findings presented in the articles. Rather than focusing specifically on digital transaction platforms and research that seeks to contribute to our understanding of these novel business models, future studies may use keywords, such as 'marketplace', 'exchange', 'trading', 'buying and selling', to consider how recent studies with these keywords empirically and theoretically consider digital transaction platforms and the platform revolution.

\section{REFERENCES}

Abbott, Martin, and Jennifer McKinney (2013), “Content analysis," In Martin Abbott and Jennifer Mckinney (Eds.), Understanding and applying research design, wheel of science: Designs of research, Hoboken, NJ: Wiley, 316-325.

Albuquerque, Paulo, Polykarpos Pavlidis, Udi Chatow, Kay-Yut Chen, and Zainab Jamal (2012), "Evaluating promotional activities in an online two-sided market of user-generated content”, Marketing Science, 31(May-June), 406-432.

Alibaba Group (2019), “Alibaba Group Investor Relations”, Available at: https://www.alibabagroup.com/en/ir/home [Accessed 10.6.2019]

Alt, Rainer, and Stefan Klein (2011), “Twenty years of electronic markets research-looking backwards towards the future", Electronic Markets, 21 (February), 41-51.

Barcelos, Renato Hübner, Danilo C. Dantas, and Sylvain Sénécal (2018), "Watch Your Tone: How a Brand's Tone of Voice on Social Media Influences Consumer Responses", Journal of Interactive Marketing, 41(February), 60-80.

Barnes, Stuart J., and Andrew D. Pressey (2012), "In Search of the "Meta-Maven": An Examination of Market Maven Behavior across Real-Life, Web, and Virtual World Marketing Channels", Psychology and Marketing, 29(March), 167-185. 
Belk, Russell (2014), "You are what you can access: Sharing and collaborative consumption online", Journal of Business Research, 67(August), 1595-1600.

Bharadwaj, Anandhi, Omar El Sawy, Paul Pavlou, and N. Venkatraman (2013), "Digital business strategy: toward a next generation of insights", MIS Quarterly 37 (June), 471-482.

Bollinger, B. and Yao, S., (2018). "Risk transfer versus cost reduction on two-sided microfinance platforms". Quantitative Marketing and Economics, 16(3), pp.251-287.

Brynjolfsson, Erik and Andrew McAfee (2014), “The Second Machine Age: Work, Progress, and Prosperity in a Time of Brilliant Technologies", W. W. Norton and Company.

Burtch, Gordon, Seth Carnahan, and Brad N. Greenwood (2018), "Can you gig it? An empirical examination of the gig economy and entrepreneurial activity", Management Science (ePub ahead of print), https://doi.org/10.1287/mnsc.2017.2916.

Caldieraro, Fabio, Jonathan Z. Zhang, Marcus Cunha Jr, and Jeffrey D. Shulman (2018), "Strategic Information Transmission in Peer-to-Peer Lending Markets", Journal of Marketing, 82 (March), 4263.

Chakravarty, Anindita, Alok Kumar, and Rajdeep Grewal (2014), "Customer orientation structure for internet-based business-to-business platform firms", Journal of Marketing, 78(September), 1-23.

Chiu, Ya-Ling, Lu-Jui Chen, Jiangze Du, and Yuan-Teng Hsu (2018), "Studying the relationship between the perceived value of online group-buying websites and customer loyalty: The moderating role of referral rewards", Journal of Business and Industrial Marketing, 33(Fall), 665-679.

Cennamo, Carmelo. and Juan Santalo (2013), "Platform competition: Strategic trade-offs in platform markets", Strategic Management Journal, 34 (September), 1331-1350.

Cho, Yung-Jan, Pei-Wen Fu, and Chi-Cheng Wu (2017), "Popular Research Topics in Marketing Journals, 1995-2014”, Journal of Interactive Marketing, 40 (November), 52-72.

Chu, Junhong and Puneet Manchanda (2016), "Quantifying cross and direct network effects in online consumer-to-consumer platforms", Marketing Science, 35 (November-December), 870-893.

Colquitt, Jason A., and Cindy P. Zapata-Phelan (2007), "Trends in theory building and theory testing: A five-decade study of the Academy of Management Journal", Academy of Management Journal, 50 (December), 1281-1303.

Crittenden, Andrew B., Victoria L. Crittenden, and William F. Crittenden (2017), "Industry transformation via channel disruption”, Journal of Marketing Channels, 24 (August), 13-26.

Datta, Hannes, George Knox, and Bart J. Bronnenberg (2018), "Changing their tune: How consumers' adoption of online streaming affects music consumption and discovery", Marketing Science, 37 (September), 5-21.

de Vaus, David (2001), “Research Design in Social Research”, London: Sage. 
Emarketer. 2018. "Amazon now has nearly 50\% of US Ecommerce Market". Available at: https://retail.emarketer.com/article/amazon-now-has-nearly-50-of-us-ecommercemarket/5b48c542ebd4000b24140992 [Accessed 31.12.2018]

Evans, Peter C. and Annabelle Gawer (2016), "The rise of the platform enterprise: A global survey", New York, NY: The Center for Global Enterprise.

Fang, Eric, Xiaoling Li, Minxue Huang, and Robert W. Palmatier (2015), "Direct and indirect effects of buyers and sellers on search advertising revenues in business-to-business electronic platforms", Journal of Marketing Research 52, 3 (June), 407-422.

Gao, Hongzhi, Monica Ren, Jing Zhang, and Ruoyi Sun (2016), "Network gatekeeping in SME exporters' market entry in China”, International Marketing Review, 33 (Spring), 276-297.

Gawer, Annabelle and Michael A. Cusumanon (2014), "Industry platforms and ecosystem innovation", Journal of Product Innovation Management, 31 (September), 417-433.

Guyader, H., 2018. "No one rides for free! Three styles of collaborative consumption". Journal of Services Marketing, 32 (June), pp.692-714.

Hagiu, Andrei and Julian Wright (2015), "Multi-sided platforms", International Journal of Industrial rganization, 43 (November), 162-174.

Hall, Angela and Neil Towers (2017), "Understanding how Millennial shoppers decide what to buy: Digitally connected unseen journeys", International Journal of Retail and Distribution Management, 45(May), 498-517.

Hossain, Tanjim and John Morgan (2013), "When do markets tip? A cognitive hierarchy approach”, Marketing Science, 32 (May-June), 431-453.

Hänninen, M., Mitronen, L. and Kwan, S.K., 2019. "Multi-sided marketplaces and the transformation of retail: A service systems perspective". Journal of Retailing and Consumer Services, 49, pp.380388.

Ieva, M., De Canio, F. and Ziliani, C., 2018. "Daily deal shoppers: What drives social couponing?". Journal of Retailing and Consumer Services, 40, pp.299-303.

Jacobides, Michael G., Carmelo Cennamo, and Annabelle Gawer (2018), "Towards a theory of ecosystems", Strategic Management Journal, 39 (May), 2255-2276.

Jiang, Baojun, Kinshuk Jerath, and Kannan Srinivasan (2011). "Firm strategies in the "mid tail" of platform-based retailing”, Marketing Science, 30 (September-October), 757-775.

Kabakova, Oksana, Evgeny Plaksenkov, and Vladimir Korovkin (2016), "Strategizing for Financial Technology Platforms: Findings from Four Russian Case Studies", Psychology and Marketing, 33 (November), 1106-1111.

Kapoor, A.P. and Vij, M., (2018). "Technology at the dinner table: Ordering food online through mobile apps." Journal of Retailing and Consumer Services, 43, pp.342-351. 
Kahn, B.E., Inman, J.J. and Verhoef, P.C., (2018). "Introduction to Special Issue: Consumer Response to the Evolving Retailing Landscape". Journal of the Association for Consumer Research, 3 (Fall), pp.255-259.

Kannan, P.K., (2017). "Digital marketing: A framework, review and research agenda". International Journal of Research in Marketing, 34(Spring), pp.22-45.

Kanuri, Vamsi K., Murali K. Mantrala, and Esther Thorson (2017), "Optimizing a menu of multiformat subscription plans for ad-supported media platforms”, Journal of Marketing, 81 (March), 45-63.

Kaushik, K., Mishra, R., Rana, N.P. and Dwivedi, Y.K. (2018), "Exploring reviews and review sequences on e-commerce platform: A study of helpful reviews on Amazon", Journal of Retailing and Consumer Services, 45 (November), 21-32.

Kenney, Martin. and John Zysman (2016), "The Rise of the Platform Economy", Issues in Science and Technology, 32 (Spring), 61-69.

Khan, Lina M (2017), "Amazon's antitrust paradox", Yale Law Journal, 126 (January), 564-907.

Komarova, Loureiro Y. and Gonzalez, L. (2015), "Competition against common sense: insights on peer-to-peer lending as a tool to allay financial exclusion", International Journal of Bank Marketing, 33(Fall), 605-623.

Kuhn, Kristine M., and Amir Maleki (2017), "Micro-entrepreneurs, dependent contractors, and instaserfs: Understanding online labor platform workforces." Academy of Management Perspectives, 31 (August), 183-200.

Kumar, V (2017), "Integrating theory and practice in marketing", Journal of Marketing, 81(March), 1-7.

Lacan, Camille. and Pierre Desmet (2017), "Does the crowdfunding platform matter? Risks of negative attitudes in two-sided markets", Journal of Consumer Marketing, 34 (Fall), 472-479.

Landsman, Vardit, and Stefan Stremersch (2011). "Multihoming in two-sided markets: An empirical inquiry in the video game console industry", Journal of Marketing, 75 (November), 39-54.

Lee, J.Y., Fang, E., Kim, J.J., Li, X. and Palmatier, R.W., (2018). "The effect of online shopping platform strategies on search, display, and membership revenues", Journal of Retailing, 94(3), pp.247-264.

Li, X., Li, X. and Wang, R., (2018). “An Investigation on Incentive Strategies in Community Building in Business-to-Business Electronic Markets”, Journal of Business-to-Business Marketing, 25 (Fall), pp.261-272.

Maier, Erik, (2016) "Supply and demand on crowdlending platforms: connecting small and mediumsized enterprise borrowers and consumer investors", Journal of Retailing and Consumer Services, 33 (November), 143-153. 
Mathmann, Frank, Mathew Chylinski, Ko de Ruyter, and E. Tory Higgins (2017), "When plentiful platforms pay off: Assessment orientation moderates the effect of assortment size on choice engagement and product valuation", Journal of Retailing, 93 (June), 212-227.

McIntyre, David P., and Arati Srinivasan (2017), "Networks, platforms, and strategy: Emerging views and next steps", Strategic Management Journal, 38 (October), 141-160.

Mittendorf, Christoph (2018). "Collaborative consumption: the role of familiarity and trust among Millennials", Journal of Consumer Marketing, 35 (Summer), 377-391.

Muzellec, Laurent, Sébastien Ronteau, and Mary Lambkin (2015), "Two-sided Internet platforms: A business model lifecycle perspective", Industrial Marketing Management, 45 (February), 139150.

Park, Eunho, Rishika Rishika, Ramkumar Janakiraman, Mark B. Houston, and Byungjoon Yoo (2018), "Social dollars in online communities: The effect of product, user, and network characteristics", Journal of Marketing, 82 (January), 93-114.

Parker, Geoffrey G., and Marshall W. Van Alstyne (2005), "Two-sided network effects: A theory of information product design”, Management Science, 51 (October), 1494-1504.

Parker, Geoffrey G., Marshall W. Van Alstyne, and Sangeet Paul Choudary. (2016). Platform Revolution: How Networked Markets Are Transforming the Economy. New York: W.W. Norton.

Perks, Helen, Christian Kowalkowski, Lars Witell, and Anders Gustafsson (2017), "Network orchestration for value platform development", Industrial Marketing Management, 67 (November), 106-121.

Perren, Rebeca, and Robert V. Kozinets (2018), "Lateral Exchange Markets: How Social Platforms Operate in a Networked Economy”, Journal of Marketing, 82 (January), 20-36.

Proserpio, D., Xu, W. and Zervas, G., (2018), "You get what you give: theory and evidence of reciprocity in the sharing economy", Quantitative Marketing and Economics, 16 (Fall), pp.371-407.

Qu, Zhe, Youwei Wang, Shan Wang, and Yanhui Zhang (2013), "Implications of online social activities for e-tailers' business performance", European Journal of Marketing, 47 (August), 11901212.

Ramaswamy, Venkat, and Kerimcan Ozcan (2018), “Offerings as Digitalized Interactive Platforms: A Conceptual Framework and Implications", Journal of Marketing, 82 (July), 19-31.

Ritala, Paavo, Arash Golnam, and Alain Wegmann (2014), "Coopetition-based business models: The case of Amazon.com”, Industrial Marketing Management, 43 (February), 236-249.

Rochet, Jean-Charles, and Jean Tirole (2006), "Two-sided markets: a progress report", The RAND Journal of Economics, 37 (Autumn), 645-667.

Saarijärvi, H., Joensuu, J., Rintamaki, T. and Yrjölä, M., 2018. ”One person's trash is another person's treasure: Profiling consumer-to-consumer e-commerce in Facebook". International Journal of Retail and Distribution Management, 46 (November/December), pp.1092-1107. 
Schaefers, Tobias, Kristina Wittkowski, Sabine Benoit, and Rosellina Ferraro (2016), "Contagious effects of customer misbehavior in access-based services", Journal of Service Research, 19 (July), 321.

Seraj, Mina (2012), "We create, we connect, we respect, therefore we are: intellectual, social, and cultural value in online communities", Journal of Interactive Marketing, 26 (November), 209-222.

Shapiro, Gilbert. and John Markoff (1997), "Methods for drawing statistical inferences from text and transcripts", Text analysis for the Social Sciences, 9-31.

Song, Minjae, Eunho Park, Byungjoon Yoo, and Seongmin Jeon (2016), "Is the Daily Deal Social Shopping? An Empirical Analysis of Customer Panel Data", Journal of Interactive Marketing, 33 (February), 57-76.

Sridhar, Shrihari, Murali K. Mantrala, Prasad A. Naik, and Esther Thorson (2011), "Dynamic marketing budgeting for platform firms: Theory, evidence, and application," Journal of Marketing Research, 48 (December), 929-943.

Sriram, Srinivasaraghavan, Puneet Manchanda, Mercedes Esteban Bravo, Junhong Chu, Liye Ma, Minjae Song, Scott Shriver, and Upender Subramanian (2015), "Platforms: a multiplicity of research opportunities", Marketing Letters, 26 (June), 141-152.

Stebbins, Robert A (2001), “Exploratory research in the social sciences.”, Thousand Oaks, CA: Sage.

Thaichon, Park, and Sara Quach (2016), "Dark motives-counterfeit purchase framework: Internal and external motives behind counterfeit purchase via digital transaction platforms", Journal of Retailing and Consumer Services, 33 (November), 82-91.

Thakur, Rakhi (2018), "Customer engagement and online reviews", Journal of Retailing and Consumer Services, 41 (March), 48-59.

Tiwana, Amrit (2014), "Platform Ecosystems: Aligning Architecture, Governance, and Strategy. Burlington”, MA: Morgan Kaufmann.

Yahia, Imene Ben, Nasser Al-Neama, and Laoucine Kerbache (2018), "Investigating the drivers for social commerce in social media platforms: Importance of trust, social support and the platform perceived usage", Journal of Retailing and Consumer Services, 41 (March), 11-19.

Yrjölä, Mika, Timo Rintamäki, Hannu Saarijärvi, and Johanna Joensuu (2017), "Consumer-toconsumer e-commerce: outcomes and implications", The International Review of Retail, Distribution and Consumer Research, 27 (May), 300-315.

Whetten, David A. (1989), "What constitutes a theoretical contribution?", Academy of Management Review, 14 (October), 490-495.

Wu, Yue, Kaifu Zhang, and V. Padmanabhan (2018), "Matchmaker Competition and Technology Provision”, Journal of Marketing Research, 55 (June), 396-413. 
Zervas, Georgios, Davide Proserpio, and John W. Byers (2017), "The rise of the sharing economy: Estimating the impact of Airbnb on the hotel industry", Journal of Marketing Research, 54 (October), 687-705.

Zhang, Xianfeng, Jifeng Luo, and Qi Li (2012), "Do different reputation systems provide consistent signals of seller quality: a canonical correlation investigation of Chinese C2C marketplaces", Electronic Markets, 22 (May), 155-168.

Zhou, Wenyan, and Oliver Hinz (2016), "Determining profit-optimizing return policies-a two-step approach on data from taobao.com”, Electronic Markets, 26 (September), 103-114. 
TABLES

\begin{tabular}{|c|c|c|c|}
\hline $\begin{array}{l}\text { Research } \\
\text { Streams }\end{array}$ & B2C platforms & C2C platforms & B2B platforms \\
\hline Exchange focus & $\begin{array}{l}\text { Exchanges between businesses and } \\
\text { consumers }\end{array}$ & Exchanges between consumers & Exchanges between businesses \\
\hline $\begin{array}{l}\text { Number of } \\
\text { Articles }\end{array}$ & 28 & 16 & 7 \\
\hline Definition & $\begin{array}{l}\text { "digital intermediaries that enable } \\
\text { economic transactions between two sets } \\
\text { of agents, such as retailers and } \\
\text { customers" (Mathmann et al. 2017, } \\
\text { p.212) } \\
\text { "facilitates exchanges between buyers } \\
\text { and sellers; thus closely resembling the } \\
\text { channel of distribution" (Crittenden, } \\
\text { Crittenden and Crittenden 2017, p. 15) }\end{array}$ & $\begin{array}{l}\text { "facilitates exchange activities } \\
\text { among a network of equivalently } \\
\text { positioned economic } \\
\text { actors" (Perren and Kozinets 2018, } \\
\text { p,20) } \\
\text { "peer-to-peer- based transactions on } \\
\text { dedicated online platforms, which } \\
\text { enable users to both obtain and provide } \\
\text { valuable resources or services in } \\
\text { temporary C2C relationships" } \\
\text { (Mittendorf 2018, p. } 377)\end{array}$ & $\begin{array}{l}\text { "specific multi-sided platforms that } \\
\text { bring together two distinct but } \\
\text { interdependent groups of customers" } \\
\text { (Muzellec, Ronteau and Lambkin 2015, } \\
\text { p.139) } \\
\text { "multi-sided platforms are distinct from } \\
\text { traditional B2B relationships, in which } \\
\text { the interaction between different sides is } \\
\text { not a condition for value generation" } \\
\text { (Chakravarti, Kumar and Grewal 2014), } \\
\text { p.1) }\end{array}$ \\
\hline $\begin{array}{l}\text { Example } \\
\text { Research Areas }\end{array}$ & $\begin{array}{l}\text { Customer loyalty } \\
\text { Firm strategies } \\
\text { Industry transformation } \\
\text { Online reviews } \\
\text { Social activities }\end{array}$ & $\begin{array}{l}\text { Attitudes } \\
\text { Network effects } \\
\text { Intellectual, Social and Cultural Value } \\
\text { Reputation } \\
\text { Trust }\end{array}$ & $\begin{array}{l}\text { Advertising Revenue } \\
\text { Business-model lifecycle } \\
\text { Customer orientation } \\
\text { Incentive Strategies } \\
\text { Marketing budgeting }\end{array}$ \\
\hline $\begin{array}{l}\text { Exemplary } \\
\text { Studies }\end{array}$ & $\begin{array}{l}\text { Ramaswamy and Ozcan (2018) } \\
\text { Lacan and Desmet (2017) } \\
\text { Mathmann et al. (2017) } \\
\text { Landsman and Stremech (2011) } \\
\text { Jiang, Jerath and Srivasan (2011) }\end{array}$ & $\begin{array}{l}\text { Perren and Kozinets (2018) } \\
\text { Wu, Zhang and Padmanabhan (2018) } \\
\text { Zervas, Proserpio and Byers (2017) } \\
\text { Chu and Manchanda (2016) } \\
\text { Zhang, Luo and Li (2012) }\end{array}$ & $\begin{array}{l}\text { Li et al. } 2018 \\
\text { Perks et al. (2017) } \\
\text { Fang et al. (2015) } \\
\text { Muzellec, Ronteau and Lambkin (2015) } \\
\text { Chakravarty, Kumar and Grewal (2014) }\end{array}$ \\
\hline
\end{tabular}

\section{Table 1.}

Digital Platform Research Streams in Marketing Literature 


\begin{tabular}{|c|c|}
\hline Author(s) & Digital Platform Definition \\
\hline $\begin{array}{l}\text { Albuquerque, P., Pavlidis, P., Chatow, U., } \\
\text { Chen, K.-Y., Jamal, Z. (2012) }\end{array}$ & $\begin{array}{l}\text { "a firm/platform usually plays the role of an intermediary that maximizes its own objectives } \\
\text { by bringing together content creators, consumers, and, in some cases, advertisers. } \\
\text { Frequently, the platform obtains revenue from commissions derived from transactions of } \\
\text { products created by users, while in other cases, revenue comes from advertising, such as } \\
\text { banner ads or links placed in user Web pages." }\end{array}$ \\
\hline $\begin{array}{l}\text { Chakravarty, A., Kumar, A., Grewal, R. } \\
\text { (2014) }\end{array}$ & $\begin{array}{l}\text { "multisided platforms are distinct from traditional B2B relationships, in which the } \\
\text { interaction between the different sides is not a condition for value generation." }\end{array}$ \\
\hline $\begin{array}{l}\text { Crittenden, A.B., Crittenden, V.L., } \\
\text { Crittenden, W.F. (2017) }\end{array}$ & $\begin{array}{l}\text { "transaction platform creates a multisided marketplace and facilitates exchanges between } \\
\text { buyers and sellers; thus closely resembling the channel of distribution." }\end{array}$ \\
\hline $\begin{array}{l}\text { Fang, E., Li, X., Huang, M., Palmatier, R.W. } \\
\text { (2015) }\end{array}$ & $\begin{array}{l}\text { "a key focus of their marketing strategy is to attract both new and existing buyers and sellers } \\
\text { to their platform simultaneously." }\end{array}$ \\
\hline $\begin{array}{l}\text { Kabakova, O., Plaksenkov, E., Korovkin, V. } \\
\text { (2016) }\end{array}$ & $\begin{array}{l}\text { "a complex information technology system that introduces a peculiar way of performing an } \\
\text { important function and is open for use by customers and partners, including developers of } \\
\text { applications, merchants and agents." }\end{array}$ \\
\hline $\begin{array}{l}\text { Kanuri, V.K., Mantrala, M.K., Thorson, E. } \\
\text { (2017) }\end{array}$ & $\begin{array}{l}\text { "they serve two groups of customers with distinct preferences and interests: one group that is } \\
\text { primarily interested in consuming the content produced by the firm, and a second group, } \\
\text { advertisers, that values the firm's provision of access to the first group." }\end{array}$ \\
\hline Lacan, C., Desmet, P. (2017) & $\begin{array}{l}\text { "in a two-sided market, the platform functions as a central intermediary, in addition to } \\
\text { performing traditional communication roles." }\end{array}$ \\
\hline $\begin{array}{l}\text { Mathmann, F., Chylinski, M., de Ruyter, K., } \\
\text { Higgins, E.T. (2017) }\end{array}$ & $\begin{array}{l}\text { "The contemporary retail landscape increasingly features digital platforms-digital } \\
\text { intermediaries that enable economic transactions between two sets of agents, such as } \\
\text { retailers and customers (Sriram et al. 2014) that aggregate extensive assortments" }\end{array}$ \\
\hline Muzellec, L., Ronteau, S., Lambkin, M. (2015) & $\begin{array}{l}\text { "Two-sided platforms are specific multi-sided platforms that bring together two distinct but } \\
\text { interdependent groups of customers." }\end{array}$ \\
\hline $\begin{array}{l}\text { Park, E., Rishika, R., Janakiraman, R., } \\
\text { Houston, M.B., Yoo, B. (2018) }\end{array}$ & $\begin{array}{l}\text { "a dominant platform for individuals to form social ties with other users and share } \\
\text { information, ideas, and interests." }\end{array}$ \\
\hline Perren, R., Kozinets, R.V. (2018) & $\begin{array}{l}\text { "a market that is formed through an intermediating technology platform that facilitates } \\
\text { exchange activities among a network of equivalently positioned economic actors." }\end{array}$ \\
\hline $\begin{array}{l}\text { Sridhar, S., Mantrala, M.K., Naik, P.A., } \\
\text { Thorson, E. (2011) }\end{array}$ & $\begin{array}{l}\text { "Platform firm markets are distinguished from one-sided firm markets, in that they have two } \\
\text { or more different groups of customers." }\end{array}$ \\
\hline $\begin{array}{l}\text { Sriram, S., Manchanda, P., Bravo, M.E., Chu, } \\
\text { J., Ma, L., Song, M., Shriver, S., } \\
\text { Subramanian, U. (2015) }\end{array}$ & $\begin{array}{l}\text { "Platforms refer to intermediaries that facilitate economic interaction between two sets of } \\
\text { agents wherein the decisions of one set of agents are likely to have an effect on the other via } \\
\text { direct and/or indirect externalities." }\end{array}$ \\
\hline
\end{tabular}

Table 2.

Selected definitions of digital platforms 


\section{FIGURES}

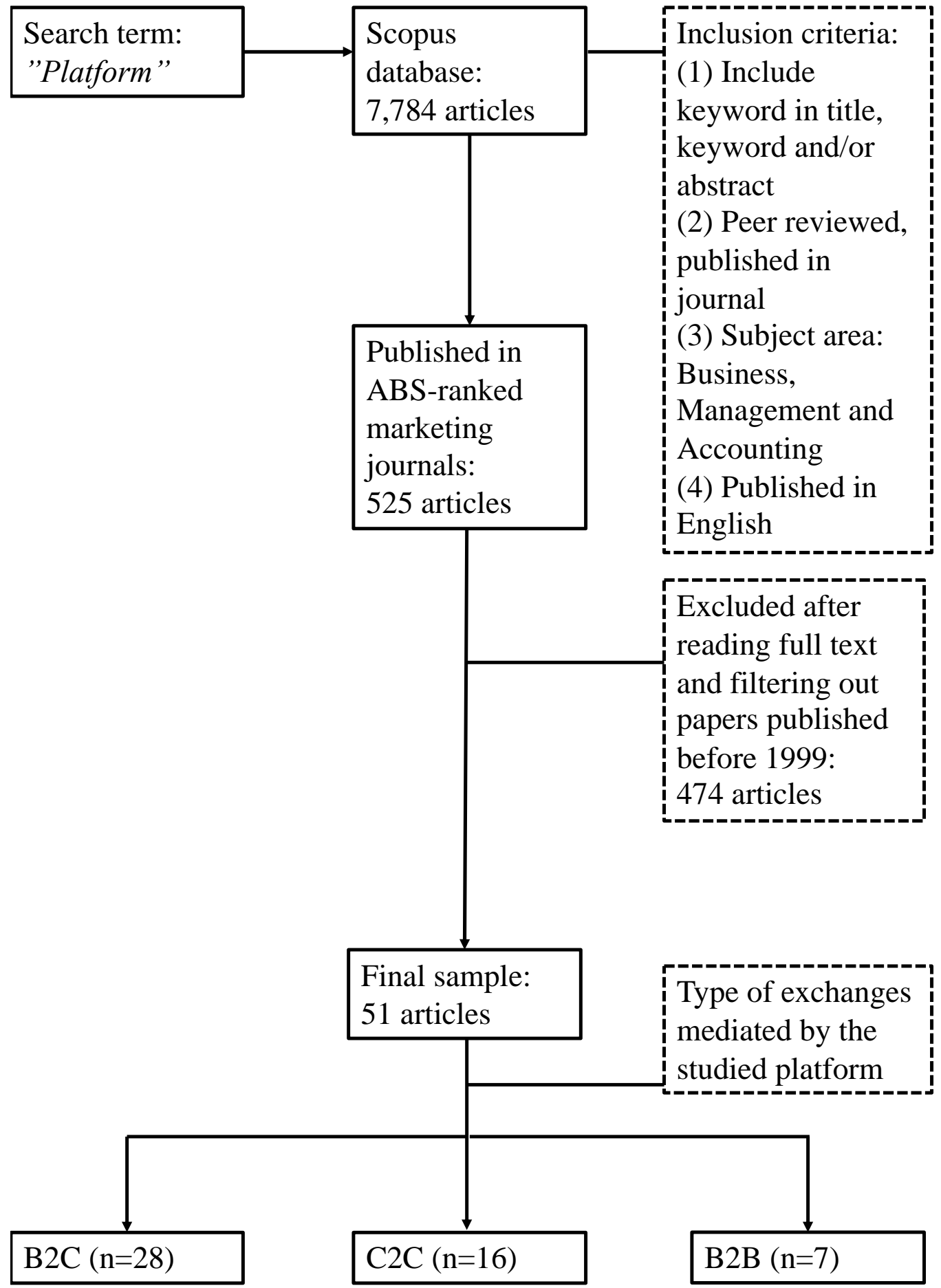

Figure 1.

An overview of the literature review 
APPENDIX

\begin{tabular}{|c|c|c|c|c|c|c|c|}
\hline Author(s) & Article title & $\begin{array}{c}\text { Publication } \\
\text { year }\end{array}$ & Journal & ABS Ranking & $\begin{array}{l}\text { Methodological } \\
\text { Approach }\end{array}$ & Data & Contribution \\
\hline $\begin{array}{l}\text { Albuquerque, Paulo, Polykarpos } \\
\text { Pavlidis, Udi Chatow, Kay-Yut } \\
\text { Chen, and Zainab Jamal }\end{array}$ & $\begin{array}{l}\text { Evaluating promotional activities in } \\
\text { an online two-sided market of user- } \\
\text { generated content }\end{array}$ & 2012 & Marketing Science & $4^{*}$ & Quantitative & Longitudinal & Theory testing \\
\hline Alt, Rainer, and Stefan Klein & $\begin{array}{l}\text { Twenty years of electronic markets } \\
\text { research - Looking backwards } \\
\text { towards the future }\end{array}$ & 2011 & Electronic Markets & 2 & Review & N/A & Exploratory \\
\hline $\begin{array}{l}\text { Barnes, Stuart J., and Andrew D. } \\
\text { Pressey }\end{array}$ & $\begin{array}{l}\text { In Search of the "Meta-Maven": An } \\
\text { Examination of Market Maven } \\
\text { Behavior across Real-Life, Web, } \\
\text { and Virtual World Marketing } \\
\text { Channels }\end{array}$ & 2012 & $\begin{array}{l}\text { Psychology and } \\
\text { Marketing }\end{array}$ & 3 & Quantitative & Survey & Theory testing \\
\hline Bollinger, Bryan and Song Yao & $\begin{array}{l}\text { Risk transfer versus cost reduction } \\
\text { on two-sided microfinances } \\
\text { platforms }\end{array}$ & 2018 & $\begin{array}{l}\text { Quantitative } \\
\text { Marketing and } \\
\text { Economics }\end{array}$ & 3 & Quantitative & Longitudinal & Theory testing \\
\hline $\begin{array}{l}\text { Caldieraro, Fabio, Jonathan Z. } \\
\text { Zhang, Marcus Cunha Jr, and } \\
\text { Jeffrey D. Shulman }\end{array}$ & $\begin{array}{l}\text { Strategic information transmission } \\
\text { in peer-to-peer lending markets }\end{array}$ & 2018 & $\begin{array}{l}\text { Journal of } \\
\text { Marketing }\end{array}$ & $4^{*}$ & Quantitative & Longitudinal & Theory testing \\
\hline $\begin{array}{l}\text { Chakravarty, Anindita, Alok } \\
\text { Kumar, and Rajdeep Grewal }\end{array}$ & $\begin{array}{l}\text { Customer orientation structure for } \\
\text { Internet-based business-to-business } \\
\text { platform firms }\end{array}$ & 2014 & $\begin{array}{l}\text { Journal of } \\
\text { Marketing }\end{array}$ & $4^{*}$ & Quantitative & Case Study & Theory building \\
\hline $\begin{array}{l}\text { Chiu, Ya-Ling, Lu-Jui Chen, } \\
\text { Jiangze Du, and Yuan-Teng Hsu }\end{array}$ & $\begin{array}{l}\text { Studying the relationship between } \\
\text { the perceived value of online group- } \\
\text { buying websites and customer } \\
\text { loyalty: the moderating role of } \\
\text { referral rewards }\end{array}$ & 2018 & $\begin{array}{l}\text { Journal of } \\
\text { Business and } \\
\text { Industrial } \\
\text { Marketing }\end{array}$ & 2 & Quantitative & Survey & Theory testing \\
\hline $\begin{array}{l}\text { Cho, Yung-Jan, Pei-Wen Fu, and } \\
\text { Chi-Cheng Wu }\end{array}$ & $\begin{array}{l}\text { Popular Research Topics in } \\
\text { Marketing Journals, 1995-2014 }\end{array}$ & 2017 & $\begin{array}{l}\text { Journal of } \\
\text { Interactive } \\
\text { Marketing }\end{array}$ & 3 & Review & N/A & Exploratory \\
\hline $\begin{array}{l}\text { Chu, Junhong and Puneet } \\
\text { Manchanda }\end{array}$ & $\begin{array}{l}\text { Quantifying cross and direct } \\
\text { network effects in online consumer- } \\
\text { to-consumer platforms }\end{array}$ & 2016 & Marketing Science & $4^{*}$ & Quantitative & Longitudinal & Theory testing \\
\hline $\begin{array}{l}\text { Crittenden, Andrew B., Victoria } \\
\text { L. Crittenden, and William F. } \\
\text { Crittenden }\end{array}$ & $\begin{array}{l}\text { Industry Transformation via } \\
\text { Channel Disruption }\end{array}$ & 2017 & $\begin{array}{l}\text { Journal of } \\
\text { Marketing } \\
\text { Channels }\end{array}$ & 1 & Review & N/A & Exploratory \\
\hline $\begin{array}{l}\text { Datta, Hannes, George Knox, and } \\
\text { Bart J. Bronnenberg }\end{array}$ & $\begin{array}{l}\text { Changing their tune: How } \\
\text { consumers' adoption of online } \\
\text { streaming affects music } \\
\text { consumption and discovery }\end{array}$ & 2018 & Marketing Science & $4^{*}$ & Quantitative & Longitudinal & Theory building \\
\hline $\begin{array}{l}\text { Fang, Eric, Xiaoling Li, Minxue } \\
\text { Huang, and Robert Palmatier }\end{array}$ & $\begin{array}{l}\text { Direct and indirect effects of buyers } \\
\text { and sellers on search advertising } \\
\text { revenues in business-to-business } \\
\text { electronic platforms' }\end{array}$ & 2015 & $\begin{array}{l}\text { Journal of } \\
\text { Marketing } \\
\text { Research }\end{array}$ & $4^{*}$ & Quantitative & Longitudinal & Theory testing \\
\hline $\begin{array}{l}\text { Gao, Hongzhi, Monica Ren, Jing } \\
\text { Zhang, and Ruoyi Sun }\end{array}$ & $\begin{array}{l}\text { Network gatekeeping in SME } \\
\text { exporters' market entry in China }\end{array}$ & 2016 & $\begin{array}{l}\text { International } \\
\text { Marketing Review }\end{array}$ & 3 & Qualitative & Interviews & Theory testing \\
\hline
\end{tabular}




\begin{tabular}{|c|c|c|c|c|c|c|c|}
\hline Guyader, Hugo & $\begin{array}{l}\text { No one rider for free! Three styles } \\
\text { of collaborative consumption }\end{array}$ & 2018 & $\begin{array}{l}\text { Journal of } \\
\text { Services } \\
\text { Marketing }\end{array}$ & 2 & Qualitative & Netnography & Theory testing \\
\hline Hall, Angela and Neil Towers & $\begin{array}{l}\text { Understanding how Millennial } \\
\text { shoppers decide what to buy: } \\
\text { Digitally connected unseen } \\
\text { journeys }\end{array}$ & 2017 & $\begin{array}{l}\text { International } \\
\text { Journal of Retail } \\
\text { and Distribution } \\
\text { Management }\end{array}$ & 2 & Quantitative & Survey & Exploratory \\
\hline $\begin{array}{l}\text { Hossain, Tanjim and John } \\
\text { Morgan }\end{array}$ & $\begin{array}{l}\text { When do markets tip? A cognitive } \\
\text { hierarchy approach }\end{array}$ & 2013 & Marketing Science & $4^{*}$ & $\begin{array}{l}\text { Mathematical } \\
\text { modeling }\end{array}$ & N/A & Exploratory \\
\hline $\begin{array}{l}\text { Ieva, Marco, Francesca Di Canio, } \\
\text { and Cristina Ziliani }\end{array}$ & $\begin{array}{l}\text { Daily deal shoppers: What drives } \\
\text { social couponing? }\end{array}$ & 2018 & $\begin{array}{l}\text { Journal of } \\
\text { Retailing and } \\
\text { Consumer } \\
\text { Services }\end{array}$ & 2 & Quantitative & Survey & Theory testing \\
\hline $\begin{array}{l}\text { Jiang, Baojun, Kinshuk Jerath, } \\
\text { and Kannan Srinivasan }\end{array}$ & $\begin{array}{l}\text { Firm strategies in the "mid tail" of } \\
\text { platform-based retailing }\end{array}$ & 2011 & Marketing Science & $4 *$ & $\begin{array}{l}\text { Mathematical } \\
\text { modeling }\end{array}$ & N/A & Exploratory \\
\hline $\begin{array}{l}\text { Kabakova, Oksana, Evgeny } \\
\text { Plaksenkov, and Vladimir } \\
\text { Korovkin }\end{array}$ & $\begin{array}{l}\text { Strategizing for Financial } \\
\text { Technology Platforms: Findings } \\
\text { from Four Russian Case Studies }\end{array}$ & 2016 & $\begin{array}{l}\text { Psychology and } \\
\text { Marketing }\end{array}$ & 3 & Qualitative & Case study & Theory testing \\
\hline $\begin{array}{l}\text { Kanuri, Vamsi K., Murali K. } \\
\text { Mantrala, and Esther Thorson }\end{array}$ & $\begin{array}{l}\text { Optimizing a menu of multiformat } \\
\text { subscription plans for ad-supported } \\
\text { media platforms }\end{array}$ & 2017 & $\begin{array}{l}\text { Journal of } \\
\text { Marketing }\end{array}$ & $4^{*}$ & Quantitative & Longitudinal & Theory building \\
\hline $\begin{array}{l}\text { Kapoor, Anuj Pal, and Madhu } \\
\text { Vij }\end{array}$ & $\begin{array}{l}\text { Technology at the dinner table: } \\
\text { Ordering food online through } \\
\text { mobile apps }\end{array}$ & 2018 & $\begin{array}{l}\text { Journal of } \\
\text { Retailing and } \\
\text { Consumer } \\
\text { Services }\end{array}$ & 2 & Quantitative & Survey & Theory testing \\
\hline $\begin{array}{l}\text { Kaushik, K., Mishra, R., Rana, } \\
\text { N.P. and Dwivedi, Y.K. }\end{array}$ & $\begin{array}{l}\text { Exploring reviews and review } \\
\text { sequences on e-commerce platform: } \\
\text { A study of helpful reviews on } \\
\text { Amazon.in }\end{array}$ & 2018 & $\begin{array}{l}\text { Journal of } \\
\text { Retailing and } \\
\text { Consumer } \\
\text { Services }\end{array}$ & 2 & Quantitative & Longitudinal & Theory testing \\
\hline $\begin{array}{l}\text { Lacan, Camille. and Pierre } \\
\text { Desmet }\end{array}$ & $\begin{array}{l}\text { Does the crowdfunding platform } \\
\text { matter? Risks of negative attitudes } \\
\text { in two-sided markets }\end{array}$ & 2017 & $\begin{array}{l}\text { Journal of } \\
\text { Consumer } \\
\text { Marketing }\end{array}$ & 1 & Quantitative & Survey & Theory testing \\
\hline $\begin{array}{l}\text { Landsman, Vardit, and Stefan } \\
\text { Stremersch }\end{array}$ & $\begin{array}{l}\text { Multihoming in two-sided markets: } \\
\text { An empirical inquiry in the video } \\
\text { game console industry }\end{array}$ & 2011 & $\begin{array}{l}\text { Journal of } \\
\text { Marketing }\end{array}$ & $4 *$ & Quantitative & Longitudinal & Theory testing \\
\hline $\begin{array}{l}\text { Lee, Ju-Yeon, Eric Fang Er, Jisu } \\
\text { J. Kim, Xiaoling Li, and Robert } \\
\text { Palmatier }\end{array}$ & $\begin{array}{l}\text { The effect of online shopping } \\
\text { platform strategies on search, } \\
\text { display, and membership revenues }\end{array}$ & 2018 & $\begin{array}{l}\text { Journal of } \\
\text { Retailing }\end{array}$ & 4 & Quantitative & Experiment & Theory testing \\
\hline $\begin{array}{l}\text { Li, Xiaoling, Xinijan Li, and Rui } \\
\text { Wang }\end{array}$ & $\begin{array}{l}\text { An Investigation on Incentive } \\
\text { Strategies in Community Building } \\
\text { in Business-to-Business Electronic } \\
\text { Markets }\end{array}$ & 2018 & $\begin{array}{l}\text { Journal of } \\
\text { Business-to- } \\
\text { Business } \\
\text { Marketing }\end{array}$ & 2 & Quantitative & Longitudinal & Theory testing \\
\hline $\begin{array}{l}\text { Loureiro, Komarova, Y. \& } \\
\text { Gonzalez, L. }\end{array}$ & $\begin{array}{l}\text { Competition against common sense: } \\
\text { Insights on peer-to-peer lending as } \\
\text { a tool to allay financial exclusion }\end{array}$ & 2015 & $\begin{array}{l}\text { Marketing } \\
\text { Intelligence and } \\
\text { Planning }\end{array}$ & 1 & Quantitative & Experiment & Theory testing \\
\hline Maier, Erik & $\begin{array}{l}\text { Supply and demand on } \\
\text { crowdlending platforms: connecting } \\
\text { small and medium-sized enterprise } \\
\text { borrowers and consumer investors }\end{array}$ & 2016 & $\begin{array}{l}\text { Journal of } \\
\text { Retailing and } \\
\text { Consumer } \\
\text { Services }\end{array}$ & 2 & Quantitative & Longitudinal & Theory testing \\
\hline
\end{tabular}




\begin{tabular}{|c|c|c|c|c|c|c|c|}
\hline $\begin{array}{l}\text { Mathmann, Frank, Mathew } \\
\text { Chylinski, Ko de Ruyter, and E. } \\
\text { Tory Higgins }\end{array}$ & $\begin{array}{l}\text { When Plentiful Platforms Pay Off: } \\
\text { Assessment Orientation Moderates } \\
\text { the Effect of Assortment Size on } \\
\text { Choice Engagement and Product } \\
\text { Valuation }\end{array}$ & 2017 & $\begin{array}{l}\text { Journal of } \\
\text { Retailing }\end{array}$ & 4 & Quantitative & Experiment & Theory testing \\
\hline Mittendorf, Christoph & $\begin{array}{l}\text { Collaborative consumption: the role } \\
\text { of familiarity and trust among } \\
\text { Millennials }\end{array}$ & 2018 & $\begin{array}{l}\text { Journal of } \\
\text { Consumer } \\
\text { Marketing }\end{array}$ & 1 & Quantitative & Survey & Theory testing \\
\hline $\begin{array}{l}\text { Muzellec, Laurent, Sèbastien } \\
\text { Ronteau, and Mary Lambkin }\end{array}$ & $\begin{array}{l}\text { Two-sided Internet platforms: A } \\
\text { business model lifecycle } \\
\text { perspective }\end{array}$ & 2015 & $\begin{array}{l}\text { Industrial } \\
\text { Marketing } \\
\text { Management }\end{array}$ & 3 & Qualitative & Case study & Theory testing \\
\hline $\begin{array}{l}\text { Park, Eunho, Rishika Rishika, } \\
\text { Ramkumar Janakiraman, Mark } \\
\text { B. Houston, and Byungjoon Yoo }\end{array}$ & $\begin{array}{l}\text { Social dollars in online } \\
\text { communities: The effect of product, } \\
\text { user, and network characteristics }\end{array}$ & 2018 & $\begin{array}{l}\text { Journal of } \\
\text { Marketing }\end{array}$ & $4 *$ & Quantitative & Longitudinal & Theory testing \\
\hline $\begin{array}{l}\text { Perks, Helen, Christian } \\
\text { Kowalkowski, Lars Witell, and } \\
\text { Anders Gustafsson }\end{array}$ & $\begin{array}{l}\text { Network orchestration for value } \\
\text { platform development }\end{array}$ & 2017 & $\begin{array}{l}\text { Industrial } \\
\text { Marketing } \\
\text { Management }\end{array}$ & 3 & Qualitative & Case study & Theory testing \\
\hline $\begin{array}{l}\text { Perren, Rebeca, and Robert V. } \\
\text { Kozinets }\end{array}$ & $\begin{array}{l}\text { Lateral exchange markets: How } \\
\text { social platforms operate in a } \\
\text { networked economy }\end{array}$ & 2018 & $\begin{array}{l}\text { Journal of } \\
\text { Marketing }\end{array}$ & $4^{*}$ & Qualitative & Ethnography & Theory building \\
\hline $\begin{array}{l}\text { Proserpio, Davide, and Georgios } \\
\text { Zervas }\end{array}$ & $\begin{array}{l}\text { You get what you give: theory and } \\
\text { evidence of reciprocity in the } \\
\text { sharing economy }\end{array}$ & 2018 & $\begin{array}{l}\text { Quantitative } \\
\text { Marketing and } \\
\text { Economics }\end{array}$ & 3 & Quantitative & Longitudinal & Theory testing \\
\hline $\begin{array}{l}\text { Qu, Zhe, Youwei Wang, Shan } \\
\text { Wang, and Yanhui Zhang }\end{array}$ & $\begin{array}{l}\text { Implications of online social } \\
\text { activities for e-tailers' business } \\
\text { performance }\end{array}$ & 2013 & $\begin{array}{l}\text { European Journal } \\
\text { of Marketing }\end{array}$ & 3 & Quantitative & Longitudinal & Theory testing \\
\hline $\begin{array}{l}\text { Ramaswamy, Venkat, and } \\
\text { Kerimcan Ozca }\end{array}$ & $\begin{array}{l}\text { Offerings as digitalized interactive } \\
\text { platforms: A conceptual framework } \\
\text { and implications }\end{array}$ & 2018 & $\begin{array}{l}\text { Journal of } \\
\text { Marketing }\end{array}$ & $4^{*}$ & Conceptual & N/A & Theory building \\
\hline $\begin{array}{l}\text { Ritala, Paavo, Arash Golnam, } \\
\text { and Alain Wegmann }\end{array}$ & $\begin{array}{l}\text { Coopetition-based business models: } \\
\text { The case of Amazon.com }\end{array}$ & 2014 & $\begin{array}{l}\text { Industrial } \\
\text { Marketing } \\
\text { Management }\end{array}$ & 3 & Qualitative & Case study & Theory building \\
\hline $\begin{array}{l}\text { Saarijärvi, Hannu, Johanna } \\
\text { Joensuu, Timo Rintamäki, and } \\
\text { Mika Yrjölä }\end{array}$ & $\begin{array}{l}\text { One person's trash is another } \\
\text { person's treasure: Profiling } \\
\text { consumer-to-consumer e-commerce } \\
\text { in Facebook }\end{array}$ & 2018 & $\begin{array}{l}\text { International } \\
\text { Journal of Retail } \\
\text { \& Distribution } \\
\text { Management }\end{array}$ & 2 & Quantitative & Survey & Theory building \\
\hline Seraj, Mina & $\begin{array}{l}\text { We Create, We Connect, We } \\
\text { Respect, Therefore We Are: } \\
\text { Intellectual, Social, and Cultural } \\
\text { Value in Online Communities }\end{array}$ & 2012 & $\begin{array}{l}\text { Journal of } \\
\text { Interactive } \\
\text { Marketing }\end{array}$ & 3 & Qualitative & Netnography & Theory testing \\
\hline $\begin{array}{l}\text { Song, Minjae, Eunho Park, } \\
\text { Byungjoon Yoo, and Seongmin } \\
\text { Jeon }\end{array}$ & $\begin{array}{l}\text { Is the Daily Deal Social Shopping?: } \\
\text { An Empirical Analysis of Customer } \\
\text { Panel Data }\end{array}$ & 2016 & $\begin{array}{l}\text { Journal of } \\
\text { Interactive } \\
\text { Marketing }\end{array}$ & 3 & Quantitative & Longitudinal & Theory testing \\
\hline $\begin{array}{l}\text { Sridhar, Shrihari, Murali K. } \\
\text { Mantrala, Prasad A. Naik, and } \\
\text { Esther Thorson }\end{array}$ & $\begin{array}{l}\text { Dynamic marketing budgeting for } \\
\text { platform firms: Theory, evidence, } \\
\text { and application }\end{array}$ & 2011 & $\begin{array}{l}\text { Journal of } \\
\text { Marketing } \\
\text { Research }\end{array}$ & $4^{*}$ & Quantitative & Longitudinal & Theory testing \\
\hline $\begin{array}{l}\text { Sriram, Srinivasaraghavan, } \\
\text { Puneet Manchanda, Mercedes } \\
\text { Esteban Bravo, Junhong Chu, } \\
\text { Liye Ma, Minjae Song, Scott }\end{array}$ & $\begin{array}{l}\text { Platforms: a multiplicity of research } \\
\text { opportunities }\end{array}$ & 2015 & Marketing Letters & 3 & Review & N/A & Exploratory \\
\hline
\end{tabular}




\begin{tabular}{|c|c|c|c|c|c|c|c|}
\hline \multicolumn{8}{|l|}{$\begin{array}{l}\text { Shriver, and Upender } \\
\text { Subramanian }\end{array}$} \\
\hline Thaichon, Park, and Sara Quach & $\begin{array}{l}\text { Dark motives-counterfeit purchase } \\
\text { framework: Internal and external } \\
\text { motives behind counterfeit purchase } \\
\text { via digital platforms }\end{array}$ & 2016 & $\begin{array}{l}\text { Journal of } \\
\text { Retailing and } \\
\text { Consumer } \\
\text { Services }\end{array}$ & 2 & Qualitative & Interviews & Theory testing \\
\hline Thakur, Rakhi & $\begin{array}{l}\text { Customer engagement and online } \\
\text { reviews }\end{array}$ & 2018 & $\begin{array}{l}\text { Journal of } \\
\text { Retailing and } \\
\text { Consumer } \\
\text { Services }\end{array}$ & 2 & Quantitative & Survey & Theory testing \\
\hline $\begin{array}{l}\text { Wu, Yue, Kaifu Zhang, and V. } \\
\text { Padmanabhan }\end{array}$ & $\begin{array}{l}\text { Matchmaker competition and } \\
\text { technology provision }\end{array}$ & 2018 & $\begin{array}{l}\text { Journal of } \\
\text { Marketing } \\
\text { Research }\end{array}$ & $4^{*}$ & $\begin{array}{l}\text { Mathematical } \\
\text { modeling }\end{array}$ & N/A & Exploratory \\
\hline $\begin{array}{l}\text { Yahia, Imene Ben, Nasser Al- } \\
\text { Neama, and Laoucine Kerbache }\end{array}$ & $\begin{array}{l}\text { Investigating the drivers for social } \\
\text { commerce in social media } \\
\text { platforms: Importance of trust, } \\
\text { social support and the platform } \\
\text { perceived usage }\end{array}$ & 2018 & $\begin{array}{l}\text { Journal of } \\
\text { Retailing and } \\
\text { Consumer } \\
\text { Services }\end{array}$ & 2 & Quantitative & Survey & Theory testing \\
\hline $\begin{array}{l}\text { Yrjölä, Mika, Timo Rintamäki, } \\
\text { Hannu Saarijärvi, and Johanna } \\
\text { Joensuu }\end{array}$ & $\begin{array}{l}\text { Consumer-to-consumer e- } \\
\text { commerce: outcomes and } \\
\text { implications }\end{array}$ & 2017 & $\begin{array}{l}\text { International } \\
\text { Review of Retail, } \\
\text { Distribution and } \\
\text { Consumer } \\
\text { Research }\end{array}$ & 1 & Quantitative & Survey & Theory building \\
\hline $\begin{array}{l}\text { Zervas, Georgios, Davide } \\
\text { Proserpio, and John W. Byers }\end{array}$ & $\begin{array}{l}\text { The rise of the sharing economy: } \\
\text { Estimating the impact of airbnb on } \\
\text { the hotel industry }\end{array}$ & 2017 & $\begin{array}{l}\text { Journal of } \\
\text { Marketing } \\
\text { Research }\end{array}$ & $4^{*}$ & Quantitative & Longitudinal & Theory testing \\
\hline $\begin{array}{l}\text { Zhang, Xianfeng, Jifeng Luo, and } \\
\text { Qi Li }\end{array}$ & $\begin{array}{l}\text { Do different reputation systems } \\
\text { provide consistent signals of seller } \\
\text { quality: A canonical correlation } \\
\text { investigation of Chinese C2C } \\
\text { marketplaces }\end{array}$ & 2012 & Electronic Markets & 2 & Quantitative & Longitudinal & Theory testing \\
\hline Zhou, Wenyan, and Oliver Hinz & $\begin{array}{l}\text { Determining profit-optimizing } \\
\text { return policies - a two-step } \\
\text { approach on data from taobao.com }\end{array}$ & 2016 & Electronic Markets & 2 & Quantitative & Longitudinal & Theory testing \\
\hline
\end{tabular}

\section{Appendix 1.}

The 51 articles included in the "final set" 